\title{
Elements to be established by brand owners seeking redress in court for trademark infringement on social media sites
}

\author{
Dr Anan Younes, Assistant Professor, College of Law, Al-Falah University-Dubai, UAE. \\ Dr Hasan Mustafa, Dean of College of Mass Communication, Al-Falah University - Dubai, UAE. \\ Dr Ahmed kamel, Assistant Professor, College of Mass Communication, Al-Falah University - Dubai, UAE
}

\begin{abstract}
It is not just enough for a mark holder to raise an alarm and further proceed to seek redress in court for trademark infringement. Such mark owner must establish and prove the following elements to the court - (1) unauthorised use in commerce of trademarks; (2) unauthorized use of the brand in respect to the sale of goods and services and other commercial activities; (3) unauthorized use of the mark as a trademark; (4) likelihood of confusion emanating from trademark infringement; and (5) No fair use.
\end{abstract}

Keywords: trademark, social media, infringement, unauthorized use, likelihood of confusion Received: 04.12.2020 Accepted: 21.01.2021 $\quad$ Published: 02.02.2021

\section{INTRODUCTION}

Social media platforms play a vital role of our start-up's life, and one of fastest growing consistent with the paths of development and progress. Its free and easy to use, and according to many studies and reports the number of social media users has been increased to $50 \%$ of the world population, this huge number forces a reality we should care about every single detail about it. It is allow companies to connect directly with their audience, target potential customers and know who is interested in their business, they will know them better to customized their needs and stay top of mind, generate leads, boost sales, promote content and increase the website traffic as well. As long as there are many other advantages encourage companies to use it, it reflects the misuse of trademarks as well which form a big challenge for companies to ensure their name is not being abused by misuse in social media.

\section{Unauthorised use in commerce of trademarks}

For a mark to be deemed to be used without in breach of the federal trademark statute, it must be established that such use was for commerce. The courts and various academic scholars have rightly pointed out that such use in commerce is jurisdictional and this means that the congress can only be able to regulate the use of such mark if it is within its powers. In Intermatic Inc. v. Toeppen, the court held that where a person uses the mark of another without authority in accounts, usernames, or other posts that is visible to the public on the internet, the requirement of commerce use can suffice owing to the fact that commerce is broad and can be quite difficult to regulate by the congress.

Section 1127 of the Lanham Act clearly defines "use in commerce" to mean the genuine use of a particular mark of another person in the ordinary usage of business. The Act also clearly states that the requirement of use in commerce can be met where the mark is placed on the goods and sold as if the infringer ere to be the authorized owner of the mark. If the mark is also used in the advertisement of goods and services, it is most likely to come within the provision of section 1127 of the Act. Courts that have interpreted the definition of section 1127 have often come to the conclusion that the "use" of mark by others is different from the "use in commerce" of such mark. Therefore, if an alleged infringer merely uses the mark of another in account names or usernames of other posts on the social media platform, the courts in adopting this definition will look at the fact that the mark as not affixed on any goods that would be transported or sold in commerce. Also, the "use in commerce" does not suffice where a person uses the mark of another for the satire, parody or commentary provided that the alleged infringer does not use the mark in the selling or advertising goods used in commerce. However, there has been another point of determining if the use and advertisement of mark by infringers can qualify as use in commerce. The clear definitions of section 1127 also provides that where the infringer makes use of the mark of another person to sell, market or advertise his or her own goods, it will surely suffice as use in commerce. An example can be seen where a seller of HD Night vision glasses known as "VisionGlobal" creates an advertisement post on the social media platform which reads thus - 
"When your eyes starts to fail you, your visions become blurry and without a vision, your purpose on earth might not be attainable. Our eyes tend to stress themselves more at night than during the day and this is can lead to eye defects. But why wait for your vision to fail you when you can enhance your night vision with our VisionGlobal HD Night vision glasses. We are the best in the market and our competitors such as "EyeMasters" cannot match our expertise in this field."

From the above post made by "VisionGlobal", it is evident that they used the trademark name of "EyeMasters" in commerce and this is a total breach of the provisions of section $1127 \mathrm{f}$ the Lanham Act. Unauthorized use of the brand in respect to the sale of goods and services and other commercial activities

This is the second element that needs to be established by a mark owner. It is quite different from the "use in commerce". In this instance, the Lanham Act clearly provides that an infringement of the registered mark of another must be use in connection to the sale, offering for sale, distribution or advertisement of any goods and services or commercial activities. There is a distinction between the "use in commerce" requirement of the Lanham Act and the requirement of "use of goods in connection with goods, services or commercial activities" brand owner might successful establish the former but fail to establish the latter, it however depends on the facts of each case. In most instances, it is always easy for the brand owner to establish that the infringer used the mark for the sell, offer of sale, distribution or advertisement of goods and services.

Here is a scenario that will meet this requirement of the Lanham Act. A competitor of Toshiba rather than Toshiba creates an account with the username ToshibaComputers on a social media network and leads the public into believing that the account is owned by Toshiba. Thereafter, the infringer creates posts via the fake social media page and offers goods and services to the public using the "Toshiba" mark while in actual sense the infringer is selling their own personal goods and services. It is evident that from this scenario, the infringers are using the brand name Toshiba for the sell, offer of sale and other commercial activities of totally different gods and services. This is surely going to come within the trademark infringement as it is misleading and most likely to tarnish the reputation of the Toshiba Company.

It needs to be noted that the unauthorized use of the trademark of another does not constitute an infringement use of the mark for the sell or offer of sale of goods and services or other commercial activities. It must be proven that the additional content on the fake account actually created a misleading sale or offer for sale of goods and services for the infringer to be liable for trademark infringement.

The infringer who comes under this element might likely argue that such sell or offer for sale of goods and services on the social media sites does not in any way constitute any likelihood of confusion. An example can be seen where a particular company that deals on Toshiba spare parts creates an account with the username "ToshibaRepairs" on Facebook, Twitter or other social media platforms. Such use of the trademark can be for referential or descriptive use and this will not come under this particular requirement.

Another defense that an alleged infringer under this requirement might come up with will be "information purpose". This usually occurs in the event wherein the accused infringer only uses the trademark for passing across information to the public. However, the brand owners are most likely to argue that the information given by the infringer falls under "information service" in a bid to meet this second requirement of the Lahman Act. Trademarks are used by a lot of companies to label and define their goods and services. Therefore the unauthorized use of such a defined goods and services can amount to trademark infringement. For example, a newspaper publication company may register and use a particular phrase or sentence in describing its goods and services. Such phrase may be - "The Tribune Times" (Goods) and also "We aim at providing you with the day to day happenings around the world to keep you informed" (services). Now when the public sees this phrase on the social media accounts opened with the name TheTribune.com, it will serve as a good notice and confirmation that the information that is being posted on the page is coming from the newspaper company.

In United We Stand Am., Inc. v. United We Stand, Am. N.Y., Inc., the court stated that services in relation to trademarks must be given the true and widest interpretation based on the circumstances of each case. Where a person uses the logo or mark of another while spreading information regarding the trademark owner, the court have often held this to amount to sale or offer for sale of 'services' under the Lahman Act.

However, it is often the case that most brand owners do not like the fact that their brand have been used without their authority and despite the fact that the motive of some infringers might be good, there are still others who will stop at nothing to make sure that the reputation of the company is painted 
in bad light. The public is most likely to be confused about the authenticity of the account and this might lead to decline in sales or business transactions for the company. In a world of technology wherein most people rely on the social media for the sales and marketing of their goods and services, most companies would not want a trademark infringer to actually rubbish their name both in the online and traditional business setting. A dismissed employee or an aggrieved customer of a particular brand may impersonate the company on social media and post misleading, destructive and bad posts about the company to the general public just to get back at the company.

Despite the fact that these brand owners may not like the fact that their brands are used to disseminate information, it will be difficult for the courts to deem such information to be a "service". In the case of Lucasfilm Ltd. v. High Frontier, the District Court for D.C held that various points of views which are provided by alleged infringers as information about the brand cannot suffice as a service under the Lahman Act governing trademark infringement. Litigation process is quite lengthy and often comes with costs. A situation where almost all forms of information disseminated by alleged infringers using marks of brand owners is taken to court will most likely create an abuse of judicial process and also stifle the free flow of ideas and information. Thus, the courts have agreed that provided such information or expression is not used by the alleged infringer for commercial advertisement purposes, it should not be classified as a service under the Lahman Act.

Despite the fact that the courts have tried to reconcile the conflict which may tend to arise from the unauthorized use of marks for disseminating of information and protection of free speech interest, the U.S Patent and Trademark Office (PTO) seems to apply more stringent measures on the registration and use of information by brand owners to amount to "information service". The PTO makes provision for brand owners to register their services as trademarks. This is due to the fact that most companies today now use websites and software Apps to communicate their goods and services to the public. However, during the registration, the brand owners in submitting the various forms must prove to the PTO that such mark is used in such a way and manner that shows commercial activity for it to be registered as information service. It also has to be shown that the proposed information on the website of the brand owner is of benefit to the public to be termed as an information service.

There are endless opportunities that are open to a lot of mark holders in the social media platforms and this is not strange to the fact they always disseminate information relating to their products on these platforms. Information is very important to the growth of a business and this is because of the growing competitive market predominantly found as a result of the use of social media platforms. However, mark holders must have an active social media manager that would at all times keep the audience thrilled and informed through regular posting of news stories and other comical contents on the social media platforms. Where a brand owner registers a mark in relation to information service, it is left for the court to decide if the unauthorized dissemination of such information on other social media sites will amount to a trademark infringement. The court in doing his will take into the consideration the intention of the alleged infringer who might use such avenue to impersonate the brand owners and carry out commercial activities using the brand. In this instance, the second requirement for trademark infringement will be satisfied.

\section{Unauthorized use of the mark as a trademark}

Section 1127 of the Lahman Act tried to give a working definition of trademark and service mark when it provided that it can be referred to any mark that is used by a person to identify and distinguish a company's goods and services as well as its sources from others. From the wordings of the above stated provision of the Lahman Act, some courts as well as notable authors have tried to conclude on the fact that trademark infringement does not occur unless the alleged infringer uses such trademark as their own trademark.

This trademark use requirement has been argued to lead to a reduction of cases of trademark infringement in the courts of law and also promote a healthy competition as well as freedom of expression. However, when it comes to the use of the mark as a trademark by the infringer on the social media sites, this is one of the defenses that the alleged infringer will likely bring up. Where the accused infringer is using the mark only for the purpose of making expressions and not for commercial purposes or placing the mark on their goods as if they were the bona fide trademark holders of such mark, the court is likely to find no act of trademark infringement. On the other hand, where from the circumstances of the case, the court finds out that the dissemination of such expression or information qualifies as service information, then it can be held that such infringer actually held out the mark as a trademark which will be caught up by this element of trademark infringement. 
Another instance wherein the courts are most likely to find that the use of a mark by an alleged infringer as a trademark amounts to a trademark infringement is when it is used in the username on social media platforms. It can be a very different case if it turns out to be that the mark was used in an expression in the comments or posts of the account. The court might not infer his to amount to holding out the term as a trademark by the infringer. The mere use of the mark on the username is likely to identify the source of the expression and represents to the public that all further information that will emanate from the social media account is deemed to be from the official trademark holders. This will create a likelihood of confusion and might have the tendency of tarnishing the reputation of the brand in the eyes of the public.

Where the alleged infringer makes use of the mark in the username or account name of the page but it failed to disclose the source where such information is emanating from, the court is likely to hold that the infringer is only trying to describe the content of the page using the mark. This means that such a person is not using the mark as a trademark. For example, if an infringer opens a Facebook or Twitter account with the username "DrinkCoca-Cola" and the account displays to the public the name of the infringer as the creator of the account, it does not amount to the source of any information that will be posted on the site.

\section{Likelihood of confusion emanating from trademark infringement.}

Where a person uses the mark of another without permission, it is most likely going to be considered under the above stated requirements as provided by the Lahman Act. The courts are duty-bound to check and ensure that the public or target audience of the brand owners will not likely by confused by the use of such mark. Therefore where there is a likelihood of confusion which is created by the creation of a social media site using another registered brand, it is often the case that the issue of impersonation will arise. However, as have been rightly mentioned earlier in this work, the test of reasonableness will be applied. In applying this test, the courts will look at whether a reasonable man is likely to believe the fake social media page created by the infringer as the official and real social media page of the brand owners.

The courts always analyze the likelihood of confusion in three folds namely - (a) The balance test in unlawful use of marks in literary and artistic works; (b) The traditional analysis for likelihood of confusion; (c) The doctrine of initial interest confusion

\section{The balance test in unlawful use of marks in literary and artistic works}

In the case of Rogers v. Grimaldi, the court laid out the tests that must be passed before a mark belonging to another can be used in the freedom of expression relating to literary and artistic works. Therefore, where a person is accused of trademark infringement, he or she may rely on the defense in the Rogers case by stating that the contents of the social media site are just literary or artistic works. It is likely that in trying to analyze the likelihood of confusion, the courts will often construe the Lahman Act in line with the unauthorized of marks for artistic and literary works. Therefore the balancing test in the Rogers case is usually employed by the courts to ensure that the interests and rights of the citizens as embodied in the First Amendment are prioritized over trademark rights. However, the courts are always at liberty to discard this test if it is evident that the use of such mark has no artistic or literary relevance to the work on the social media post and also if despite having some artistic and literary relevance, the work is totally misleading in respect to the source of the work.

The first factor for determination by the courts is with regards to the artistic relevance of the work. When an alleged infringer uses the mark of a brand owner in creation of a username or posts on a social media platform, such usage would be deemed to be artistically relevant to work on the social media site. Such expressions may or may not be about the mark holder, the court is concerned about the fact that the content must have artistic relevance to the mark used.

The second factor which the courts will apply in the Rogers test is the fact that such unauthorized use will not mislead the public into thinking that it is the source of the work. The courts will make its analysis on this issue based on the usage of the mark as well as the content of the expression and ho it tends to inform the public or audience. Where impersonation is found to be the aim for the use of the mark and the public tends to believe all the false misrepresentations by the impersonator, it is clear that the court will find this misleading from the content of expression on the site. 


\section{The traditional analysis for likelihood of confusion}

In trying to resolve the issue of likelihood of confusion which may tend to arise from the use of marks by unauthorized persons, the courts have tried to determine the strength of the mark that has been used. Popular marks such as Coca-Cola, Apple are well known to the public and they have a wide range of followers on social media platforms. However, a person or group of persons might decide to use these marks to actually run promotion/support, satire, parody, commentaries or even criticisms on the social media sites and the public would not likely be confused by such usage. Although it will be easier to clearly know when these marks are being impersonated by other people.

Where an alleged infringer uses the mark for the advertisement or commercial purpose of selling goods and services, it does not matter whether the goods and services are identical or not to that of the mark holder for prove of likelihood of confusion to arise. It is until the infringer starts to impersonate the mark holder through the use of the mark that the likelihood of confusion in respect to the source of the expression.

\section{The doctrine of initial interest confusion}

The courts have applied this doctrine I a lot of trademark infringement cases and this doctrine clearly states that any person that uses the mark of another and in the process attracts the attention of the customers creates an initial interest confusion even though the infringer did not in actual sense sell any goods and services to the customer. Most infringers have argued in their defense that this doctrine only applies where there is actual use of the mark for selling advertising or other commercial purposes as it does not apply where the use is only for expression on the social media sites.

\section{No Fair use}

The last element that is often required to be established by brand owners in trademark infringement cases is the fact that such mark was not a fair use as provided in the Lahman Act. Under the extant Trademark Infringement Act, it is not an infringement if a person while acting in good faith, actually makes use of a word or phrase from a mark to describe the origin or nature of the goods and services offered by the alleged infringer.

In the notorious case of Cosmetically Sealed Indus. v. Chesebrough-Pond's USA Co., the court held the that the usage of a phrase by the defendant constitutes a fair usage despite the fact that it is similar to the registered trademark of the plaintiff. However, when it comes to use of these words or phrases on social media sites, the courts tend to be careful in analyzing the surrounding circumstances of the case. Where an alleged infringer merely uses a word or phrase from the mark of another in a descriptive manner in the content of the social media site, it will likely not come under trademark infringement. However, where such infringer uses the word or phrase in the username which points the source of information or expression on the website, the court is likely to hold that it amounts to a trademark use and not a fair use.

There have been a lot of arguments regarding the fulfillment of this requirement especially in the situation whereby impersonation of the brand owner is identified. In this scenario, the test of reasonableness would be applied once again and obviously justified that an impersonator does not act in good faith and would likely not make fair use of the mark.

\section{Defenses to the trademark infringement}

For the purpose of this study, the US and EU descriptive use defense shall be discussed to clearly cover descriptive use of a trademark.

\section{Fair use defense}

In the United States, where a brand owner accuses a person of trademark infringement by the use of such mark in a commercial way, there are two defenses that are open to the accused person that is relying on fair use. Firstly, the nominative fair use defense can be used and secondly, the classic fair use defense can be employed. These fair use defenses are often said to be exclusively but a lot of defendants raise both of them thereby allowing the court to decide on the best defense that fits the case.

Before these defenses can be applied, the surrounding facts of the case have to be analyzed to ensure that the mark was used in a descriptive manner. For example, where the term "Lovers paradise" is used by a person on a social media site to describe a place where couples meet and play love games, any of these defenses can be adopted. 


\section{Nominative fair use defense}

It is worthy to note that there is no social media related legislation or jurisprudence governing the infringement of trademarks. Therefore the normative fair use defense used in the physical world is applied in the social media world to curb the menace of online social media trademark infringement.

The courts have actually given the definition of the normative fair use defense in the case of Saxlehner v Wagner. In the case of Société Comptoir de L'Industrie v Alexander's Dep't Stores, Inc, the court held that there is totally nothing wrong with a person using the mark of another to describe the goods and services he or she renders provided it was carried out in good faith. For an alleged infringer to successfully rely on this defense, such a person must sufficiently prove that the use of the mark was solely for descriptive purposes. Just as in the US, the defendants for trademark infringements in the EU can rely on the provisions of Article 6 Directive 2008/95/EC and Article 12 Regulation 207/2009/EC which are similar to the classic and normative fair use defense applicable in the US. However, the provisions of the above stated legislations clearly indicates that the use of the trademark must actually be carried out in utmost good faith bearing in mind the commercial usage policy.

Article 3a of Directive 84/450 later amended by Directive 97/55 clearly makes provision for comparative advertisement wherein a person may use the mark of another who is usually a competitor to describe in his or her advertisement the goods and services being offered.

\section{Classic fair use defense}

In the case of Nihon Keizai Shimbun v Comline Business Data, the court tried to define the classic fair use defense as involving the unauthorized use of a mark by another to primarily and simply describe various aspects of their goods. Just like the nominative fair use defense, the classic fair use defense is provided for by the Lanham Act, 15 U.S.C. $§ 1115$ (b) (4). This defense has been adjudged to have helped curb the instance of monopoly which registered trademark holders may seem to enjoy for registering such descriptive word or phrase. In the case of KP Permanent Make-Up, Inc. v Lasting Impression I, Inc., the Supreme Court laid down three basic tests that must be fulfilled by a person relying on the defense of classic fair use.

1. Such word or phrase must be solely used for the purpose of describing the goods and services rendered by the defendant;

2. The use of the term is not intended for the purpose of a mark;

3. When using the term, the defendant must ensure that the description is carried out in utmost good faith and fairly.

Although not provided for by the Supreme Court, a lot of scholars have actually insisted that there should be a fourth requirement stipulating that there should be an absence of the logo of the mark holder. This is because of the fact that the logo is not descriptive in nature and surely does not pass any descriptive information concerning the goods and services of the defendant to the public.

Once a defendant relies on the classic fair use defense, it behooves on the challenger to prove to the court that there was indeed a likelihood of confusion created in respect to the source of the goods and services. It has been generally posited and accepted that when a person uses the words or phrases of the registered trademark of another person, it does not in any way constitute a trademark infringement under the Lahman Act even though all the words and phrases used in the description has been earlier registered as a trademark of another entity.

Moving on, it is pertinent to point out that the descriptive fair use defense is not only open to user of social media sites but even the social media providers themselves can rely on this defense. One of the practical examples can be seen with the issue that transpired between Timelines Inc. and Facebook. Timelines sued Facebook for allegedly making use of their trademark "timeline" as one of their basic features. Facebook argued that there is a huge difference between "Timelines" and "Timeline" stating further that the only used the word to further enhance and describe one of its main features. In their argument and defense, Facebook while relying on the fair use defense stressed that they used the word in utmost good faith and in a descriptive manner without any intention to hold it out as their trademark. However, that was not the case after Mark Zuckerberg, the Facebook founder and CEO made a statement wherein he referred to the Timeline as a Facebook trademark.

Although Facebook later settled the case with Timelines Inc. as disclosed in the Facebook quarterly report submitted to the Security and Exchange Commission.

\section{First Amendment defense}

Another important defence that a defendant in a trademark infringement suit can rely on is the fact that such an expression or statement that was made in the social media site is protected by the First 
Amendment which provides for the right to freedom of expression. However, a person that is relying on this defense must clearly prove to the court that the speech or expression is non-commercial in nature and it does not present any false facts which is more likely to mislead the public. Therefore, when the challenger is relying on the relevant trademark infringement laws, the defendant can rightly point the court towards the constitutional provision which supersedes all other statutes.

Therefore where the requirement of non-commerciality and false nature of the expression is not fulfilled by the defendant, the court is likely to uphold the provisions of the trademark infringement law as against the constitutional provision of the First Amendment right to freedom of expression. Also, where the alleged infringer goes further to impersonate the brand owner thereby holding out such false information or expression to be sourced from the trademark and in the process misleading the public, the defence of the First Amendment right to freedom of expression will not suffice. The test that is employed here is whether the defendant actually presented such false information to the public intentionally with malice afore-thought or totally disregarding with recklessness the truthfulness or otherwise of the statement.

It is important to note that some of the cases in court have been decided against a defendant resting their defence on the First Amendment right to freedom of expression. This is usually the case where it is proven that the use of such expression created a likelihood of confusion among the public.

\section{No knowledge of prior use}

An alleged trademark infringer may successfully rely on this defense provided that he or she can prove that there was no knowledge of the earlier registration and use of the mark by the brand owner and also that such use was in good faith. The social media is filled with a lot of business entities and it is most likely that not all competitors have visibility knowledge of themselves. An example of this defence can be seen where a company that produces shoes uses a mark on social media on its entire product since 2010 and in 2012, the company finds out that such mark has earlier been registered by another company although such company does not have a social media presence up until 2012.

\section{Parody}

Where the defendant raises this defense, it must be proven before the court that the use of such mark was merely a joke or satire and was not intended to cause any confusion among the members of the public.

\section{CONCLUSION}

An argument for this porous, unauthorised, and easy access of the trademark of others is that the social media sites are more concerned with making profit than ensuring that other people don't lose profit. Trademark infringement on social media has caused a lot of companies millions of dollars in loss. It has also tarnished the image and reputation of a lot of brand owners on social media. This is the reason why a lot of brand owners invest heavily on account management and protection on the various social media sites which they operate in.

Despite the negative effects of trademark infringement on social media, it can also be argued that it has contributed to the general growth of other brands. This means that a brand that understands fully the dangers that are attached to trademark infringement will carry out regular and random market survey and marketing to strengthen its mark. The strength of a mark goes a long way to help the brand fight off trademark infringers. This can be done through ensuring that the social media accounts of the brand are visible on search engines and also verified on these social media platforms. Regular posting of relevant materials with a distinctive and unique style and tone attributable only to that brand goes a long way to build confidence in the users that the source of the information is official.

Most brands have now opted in to the use of video to supplement their mark and thereby selling their goods and services on various social media platforms. As it is well known that despite the technology that can be used in the editing of videos, a reasonable man can always decipher and quickly detect when a video is fake. For example, a company that is into the provision of services related to language translation and voice-overs can create marketing videos using the face of one of its staff in most of its posts on their social media handle.

While companies are left to find ways to curb the menace of trademark infringement on social media, there is also need for legislations to be made which will incorporate the unique features of the social media platforms to help brand owners fight off brandjackers, trademark infringers and impersonators. The social media providers are also charged with the responsibility of bringing out innovative ways to protect these brands while using their social media platforms. For instance, the 
innovation by Twitter and Facebook to verify certain accounts owned by brand owners is a good one that still requires improvement. Most people that use the internet are not internet savvy and will surely require much enlightenment about the features that are available on most of these social media sites.

\section{REFERENCES}

Mustafa, H. Digital Social Engineering Threatens Cybersecurity. International Journal of Innovative echnology and Exploring Engineering (IJITEE), 9(1), 4016-4025.

Digital Report, (2020)

Bhushan, A. (2006). Bosley Medical Institute v. Kremer: The Winds Shift to Protect Cybergripers and a Circuit Split Blows into Town. Ga. St. UL Rev., 23, 965.

Barker, S. N. (1996). Famous. com: Applying the FTDA to Internet Domain Names. U. Dayton L. Rev., 22, 265.

Goodberlet, K. (2006). The Trademark Dilution Revision Act of 2006: Prospective Changes to Dilution Definition, Claim Analyses, and Standard of Harm. J. High Tech. L., 6, 249.

Gámez, A. (2006). WhenU. com, Inc. \& Google Inc.: Parsing Trademark's Use Requirement. Berkeley Technology Law Journal, 21(1), 403-424.

Basenfelder, J. (2015). What's the Use? Why a Commercial Use Requirement Is Not Necessary for Infringement Claims under the Lanham Act. Temp. L. Rev. Online, 88, 78

Heymann, L. A. (2004). The birth of the authornym: Authorship, pseudonymity, and trademark law. Notre Dame L. Rev., 80, 1377.

Goldman, E. (2008). Online word of mouth and its implications for trademark law.

Dogan, S. L., \& Lemley, M. A. (2006). Grounding trademark law through trademark use. Iowa L. Rev., 92, 1669.

Ramsey, L. P. (2010). Brandjacking on social networks: Trademark infringement by impersonation of markholders. Buff. L. Rev., 58, 851.

Ramsey, L. P. (2010). Brandjacking on social networks: Trademark infringement by impersonation of markholders. Buff. L. Rev., 58, 851.

Semadeni, M. (2006). Minding your distance: How management consulting firms use service marks to position competitively. Strategic Management Journal, 27(2), 169-187.

Goldman, E. (2008). Online word of mouth and its implications for trademark law.

Goldman, E. (2005). Deregulating relevancy in Internet trademark law. Emory LJ, 54, 507.

Wawrzyniak, R. E. (1990). Unauthorized Use of a Celebrity's Name in a Movie Title: Section 43 (a) of the Lanham Act and the Right of Publicity. Mo. L. Rev., 55, 267.

Rogers, J. M., \& Molzon, R. E. (1992). Some Lessons About the Law from Self-Referential Problems in Mathematics. Michigan Law Review, 90(5), 992-1022.

Beebe, B. (2006). An empirical study of the multifactor tests for trademark infringement. Calif. L. Rev., $94,1581$.

Rothman, J. E. (2005). Initial interest confusion: standing at the crossroads of trademark law. Cardozo L. Rev., 27, 105.

Dinwoodie, G. B., \& Janis, M. D. (2006). Lessons from the trademark use debate. Iowa L. Rev., 92, 1703.

Rothman, J. E. (2005). Initial interest confusion: standing at the crossroads of trademark law. Cardozo L. Rev., 27, 105.

Ramsey, L. P. (2007). First Amendment Limitations on Trademark Rights. INTELLECTUAL PROPERTY AND INFORMATION WEALTH: ISSUES AND PRACTICES IN THE DIGITAL AGE, 3, 147.

Johnson, S. A. (2006). Century 21 Real Estate Corp. v. Lending Tree, Inc.: Making a Big Deal out of Nominative Use. Tul. J. Tech. \& Intell. Prop., 8, 207.

Brown, R. C. (1941). Regulations, Reenactment, and the Revenue Acts. Harvard Law Review, 54(3), 377 397.

Mulligan, W. H. (1976). Preliminary Injunction in the Second Circuit. Brook. L. Rev., 43, 831.

Westberg, D. J. (1994). Intellectual Property Law-New Kids On the Block v. News America Publishing, Inc.: New Nominative Use Defense Increases the Likelihood of Confusion Surrounding the Fair Use Defense to Trademark Infringement. Golden Gate UL Rev., 24, 685.

Parrott, S. (2012). News Producers Often Prevail against 'Fair Use'Claims. Newspaper Research Journal, $33(3), 6-20$.

Dillon, J. L. (1991). The Effect of Incontestability in Trademark Litigation. Denv. UL Rev., 68, 277

Make-Up, K. P. (2004). Inc. v. Lasting Impression I. Inc, 543, 121-22.

Michael G. Atkins, 'Social Media Law: Trademark Issues', Seattle Trademark Lawyer, at: 
<http://seattletrademarklawyer.com/storage/Social\%20Media\%20Law.pdf> accessed 11 February 2020

Friedmann, D. (Ed.). (2015). Trademarks and Social Media: Towards Algorithmic Justice. Edward Elgar Publishing.

Facebook, Inc., Securities and Exchange Commission, Form 10-Q, (Quarterly Report), 2 May 2013, at 33

Ramsey, L. P. (2008). Increasing First Amendment Scrutiny of Trademark Law. SMUL Rev., 61, 381.

Rosenberg, R. A. (2012). Don King Productions, Inc. v. Walt Disney Co.: Reinforcement of Actual Malice as the Seminal Defense to Public Figure Defamation Claims in Florida. Nova L. Rev., 37, 69.

Weston, B. H. (1991). Security Council Resolution 678 and Persian Gulf decision making: precarious legitimacy. American Journal of International Law, 85(3), 516-535.

Possessky, L. (2013). House of Cards. Landslide, 6, 9. 